\title{
The Implementation and Testing of Online Self-Diagnose Covid19 Application Using CBR and UAT
}

\author{
I Putu Agus Eka Pratama ${ }^{1}$ \\ ${ }^{1}$ Department of Information Technology, Faculty of Engineering, Udayana University, Indonesia
}

\begin{tabular}{|c|c|}
\hline Article Info & ABSTRACT \\
\hline Article history: & \multirow{10}{*}{$\begin{array}{l}\text { Nowadays, at Bali Province (Indonesia), one of the public services that are } \\
\text { still lacking related to the Covid19 pandemic is online self-diagnosis, so there } \\
\text { are still many people who do not know whether they are exposed or not, } \\
\text { based on general symptoms, unusual symptoms, or serious symptoms so that } \\
\text { they can be treated immediately. In this research, Covid19CBR as a } \\
\text { prototype of an online Covid19 self-diagnose application using the CBR } \\
\text { (Case-Based Reasoning) method was developed, which can be run online via } \\
\text { a web browser. Users simply input their personal data, choose the symptoms } \\
\text { experienced or felt, then the system will provide diagnostic results online. } \\
\text { This research use Design Science Research Methodology (DSRM) with the } \\
\text { case study qualitative research methods, literature study data collection } \\
\text { methods, with prototype design using Use Case Diagrams and Sequence } \\
\text { Diagrams. The application was tested using User Acceptance Testing (UAT) } \\
\text { with the results of } 95 \% \text { that mean user can use this application easily. }\end{array}$} \\
\hline Received Sept 13, 2021 & \\
\hline Revised Oct 11, 2021 & \\
\hline Accepted Oct 25, 2021 & \\
\hline Keywords: & \\
\hline Case-Based Reasoning & \\
\hline Covid19 & \\
\hline Self-diagnose & \\
\hline Design $\quad$ Science & \\
\hline & \\
\hline
\end{tabular}

DSRM

User Acceptance Testing

UAT

\section{Corresponding Author:}

I Putu Agus Eka Pratama

Dep. of Information Technology, Faculty of Engineering, Udayana University

Jln. Raya Kampus Unud, Bali, Indonesia, 80232.

Email: eka.pratama@unud.ac.id
This is an open access article under the CC BY-SA license.

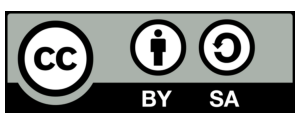

\section{INTRODUCTION}

The Covid19 pandemic in the Province of Bali (Indonesia) has not shown a significant decline since last 2020 [1-3]. One of the reasons is that not many people know their condition, whether they have been exposed to Covid-19 or not. To be able to find out whether they have been exposed to Covid-19 or not, they must go to the nearest hospital or through the help of medical personnel. This is quite inconvenient from the point of view of the community and medical personnel, in the midst of the increasing number of fatalities during this pandemic.

The rapid development of Information Technology from time to time, especially on websites and the internet, should be able to provide solutions to these problems. There is a need for Information Technology (IT)-based services that can be accessed freely, quickly, and online by everyone, to be able to independently diagnose Covid19. The service must be easily accessible from desktop and mobile devices without the constraints of differences in the platforms used, where users simply access from the device using an internet connection and an available web browser.

Through the online Covid19 diagnosis service, the public is expected to be able to find out their condition early on, whether they have the potential to be exposed to Covid-19 in the form of general symptoms, unusual symptoms, or serious symptoms, so that from the results of the online 
diagnosis, medical action can be taken immediately, either in the form of centralized isolation, selfisolation, as well as other medical measures.

Based on the background of these problems, in this research a solution is proposed in the form of application development and services in the form of a web-based information system for online and self-help diagnoses related to the symptoms of Covid19 experienced by users. The application developed is named Covid19CBR. Covid19CBR is a prototype web-based application to help users carry out online self-diagnosis related to the complaints and symptoms of Covid19 they are experiencing. Covid19CBR was developed using the Case-Based Reasoning (CBR) method as an Artificial Intelligence (AI) and data-based method. Through Covid19CBR, users simply input their data at the beginning, then select the symptoms experienced or felt, then the system will process the user input data into diagnostic information, and then the diagnostic results are displayed back to the user through a face-to-face application.

This research uses Design Science Research Methodology (DSRM) as a research methodology, along with case study qualitative research methods, literature study data collection methods, and User Acceptance Testing (UAT) methods on the user side. The system was developed using the stages in DSRM, and then implemented in the form of a web-based application on the Cloud Computing network.

Two research questions become the formulation of the problem in this research, namely: 1.) How to design and implement a web-based online Covid19 self-diagnosis application using Case Based Reasoning (CBR) and Design Science Research Methodology (DSRM) methods? 2.) How do I test the Covid19CBR application that has been developed to find out user needs and user understanding of the solutions provided?

The Case-Based Reasoning (CBR) method utilizes data and relationships between data to diagnose cases that have occurred, and then provide solutions for other cases that have previous cases [4]. There are sixteen previous researches regarding the application of the Case-Based Reasoning (CBR) method with various case studies related to health. The first research was conducted by Mage, where the CBR method was used in an application to diagnose children's diseases [5]. The second research was conducted by Adiba to develop an application for diagnosing skin diseases using the CBR method in humans [6]. The third research was conducted by Rismawan and Hartati to develop an application for diagnosing ENT diseases in humans using the CBR method [7].

The fourth research was conducted by Fatoni and Noviandha in which the CBR method was used in developing applications for diagnosing diphtheria [8]. The fifth research was conducted by Nasution, Hasibuan, and Ramadhan in developing an anorexia nervosa diagnosis system using the CBR method [9]. The sixth research was conducted by Akmal and Winiarti in the form of developing a CBRS-based gastric disease diagnosis system [10]. The seventh research was conducted by Kusuma and Chairani using the CBR method to diagnose lung disease [11]. The eighth research was conducted by Shaid, Laksito, and Utami in the form of developing a CBRbased toddler growth diagnostic application [12]. The ninth research was conducted by Gulo and Syahrizal in the form of developing a hemophilia diagnosis system using the CBR method [13].

The tenth research was conducted by Sidabutar in the form of developing an application for diagnosing the cardiovascular system in elderly humans using the CBR method [14]. The eleventh research was conducted by Amaliah, Johar, and Dharmayana in the form of developing a mental retardation diagnosis system in children using the CBR method [15]. The twelfth research was conducted by Adawiyah in the development of a dengue diagnosis system using the CBR method [16]. The thirteenth research was conducted by Papuangan in the form of developing a hepatitis diagnosis system based on the CBR method [17]. The fourteenth research was conducted by Ginting in developing a system for diagnosing kidney disease in humans using the CBR method [18]. The fifteenth research was conducted by Nas related to the development of a system for diagnosing dental and oral diseases in humans using the CBR method [19]. The sixteenth research was conducted by Widyanti, and Noranita using the CBR method for the development of a Rheumatoid Arthritis (RA) diagnosis system [20]. 
The User Acceptance Testing (UAT) assess the user's understanding of the functions and menus in an application that is proposed and developed as a solution to a problem [21]. Five previous researches apply User Accepted Testing (UAT) as a software testing method on the user side with several case studies. The first research was carried out by Listiyan and Subhiyakto, namely testing the UAT on the warehouse inventory system [22]. The second research was conducted by Wardhono, Marji, and Kusuma, wherein this research they tested UAT on Augmented Reality (AR) applications [23]. The third research was conducted by Pratama, which used the UAT testing model on the immigrant population data collection system [24]. The fourth research was conducted by Priyatna, Hananto, and Nova, in the form of a UAT testing model on an online meeting system [25]. The fifth research was carried out by Hady, Haryono, and Rahayu, namely testing the UAT on the application of santri savings in Islamic boarding schools [26].

None of these researches have utilized both Case-Based Reasoning (CBR) and User Accepted Testing (UAT) method for the diagnosis of Covid19. This has become a research gap that the author took to be used as a research topic on PUPS 2021 Batch 2 research grant. For this reason, in this research, there is an added value and research contribution in the form of using the CBR method model for the diagnosis of Covid19 based on input complaints from users, combined with UAT methods to testing the application that has been developed to find out the user needs.

\section{RESEARCH METHOD}

\subsection{Hardware and Software}

This research was conducted from May 2021 until September 2021. The hardware used is Dell Latitude E6440 (Intel 17-4610M (4) @ 3.700GHz, 16GB of RAM). The software used is Ubuntu Linux 20.04, Apache, PHP, MySQL, JavaScript, P5.js, HMTL5, HTML5 canvas, Mappa, Leaflet, and Google Firebase.

\subsection{Design Science Research Methodology (DSRM)}

This research aims to provide a Covid19 self-diagnose service solution to the public online using the Case-Based Reasoning method. This research use Design Science Research Methodology (DSRM) with the case study qualitative research methods, literature study data collection methods. DSRM consist of seven sequential steps as shown in Figure 1. below:

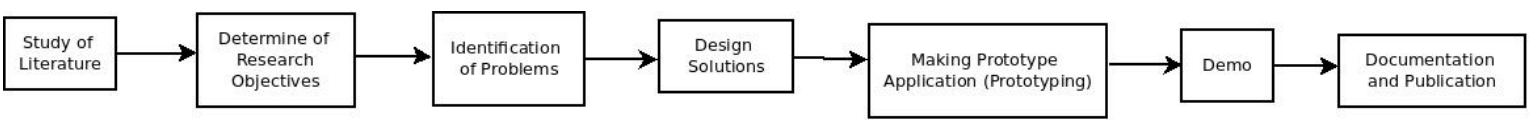

Figure 1. DSRM with 7 sequential steps

From Figure 1. above, DSRM was introduced by Peffers, et al., which includes seven research steps, namely: a study of literature, determine of research objectives, identification of the problem, design solutions, making prototype application (prototyping), demo, documentation and publication [27-30]. The literature study was carried out through the collection of several pieces of literature related to the Covid19 case in Bali Province as well as several uses of the CBR method and AI as state of the art. The research motivation is determined through efforts to create a webbased system that can help citizen to diagnose if he/she has symptoms of Covid19 or not so that early detection, prevention, and treatment can be done quickly. Problem identification is formulated into research questions using the $5 \mathrm{~W}+1 \mathrm{H}$ formulation.

The solution design is given in the form of both Use Case and Sequence Diagrams. In this research, two-actor namely Pengguna (user) and Administrator (admin) was shown in Use Case Diagram as a set of sequence interaction, as shown in Figure 2. below: 


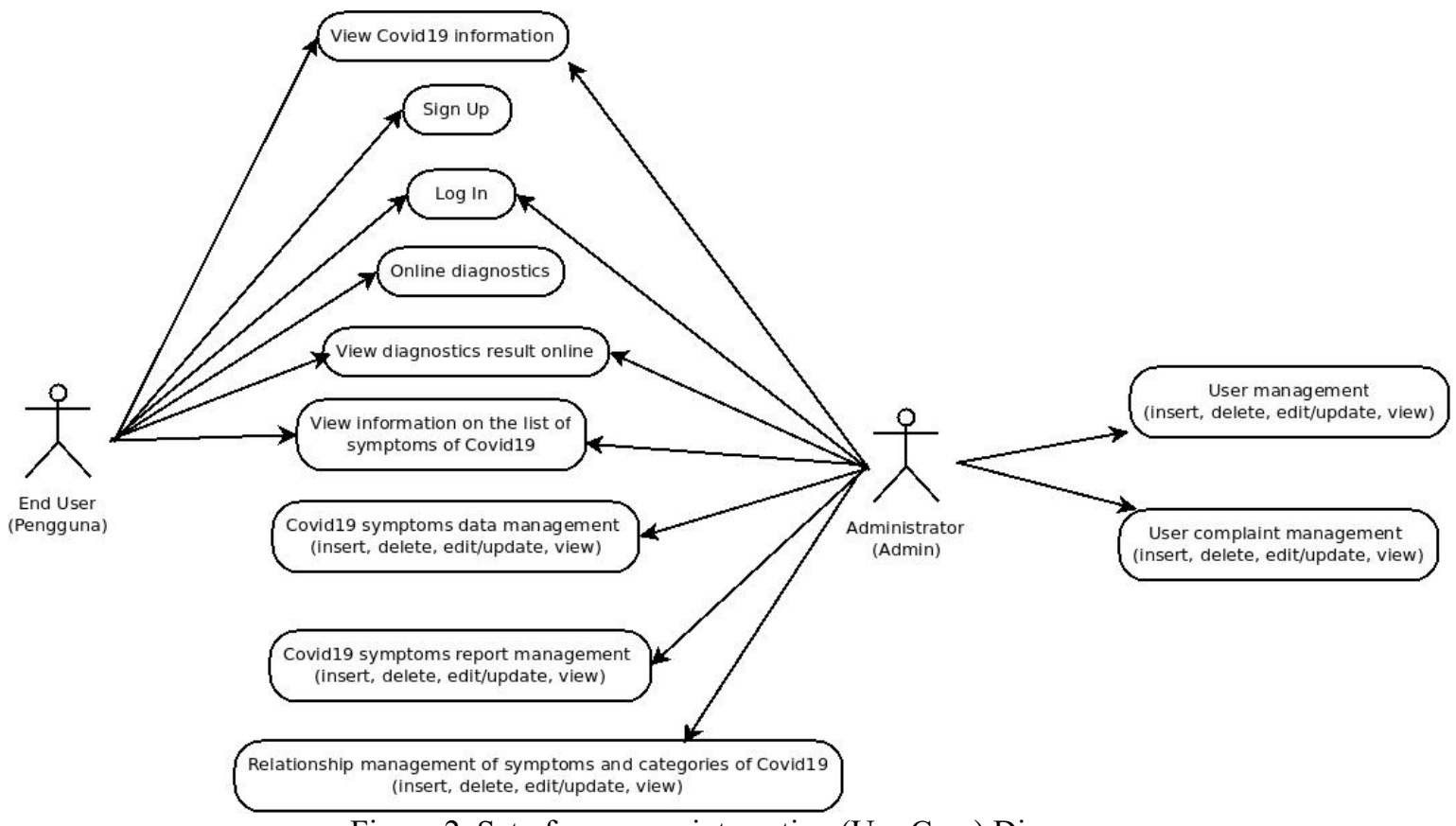

Figure 2. Set of sequence interaction (Use Case) Diagram

From Figure 2. above, it can be shown that there are two actors in the Use Case Diagram, namely User (user) and Administrator (admin). Users have access rights to several menus in the application, namely: Sign Up, Login, View Covid19 Information, Online Diagnostics, View Diagnostic Result Online, and View Information on the list of Symptoms of Covid19. Meanwhile, the Administrator has access to all menus in the application, namely all menus that can be accessed by Users along with additional data management menus which include: User Management, User Complain Management, Covid19 Symptom Management, Covid19 Symptom Report Management, and Relationship Management of Symptom and Categories of Covid19.

A Sequence Diagram (system sequence) developed from Use Case Diagram to describe in more detail each step of the process in it. In this case, View Covid19 Information Use Case through accessing the application URL, can be presented in the form of a System Sequence Diagram, as shown in Figure 3. below:

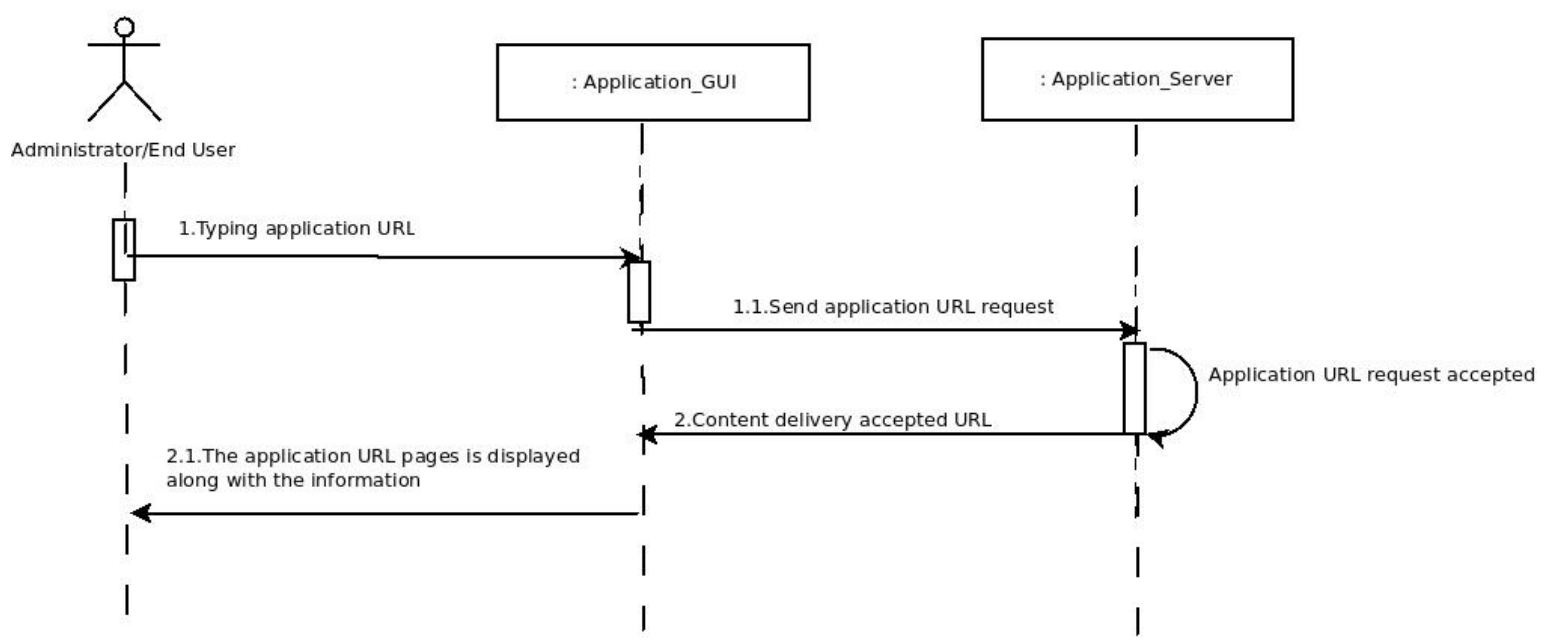

Figure 3. System Sequence Diagram

From Figure 3. above, it can be seen that to be able to view Covid19 information on the application, the user (Administrator and End User) must access the application URL via a web browser. First of all, the user types the application URL in the application interface in a web browser (Application GUI), and then sends the application URL request to the server. After the 
request is received, then the content will be sent back to the user through a face-to-face web-based application where users can view Covid19 information on the application web page as needed.

\subsection{Case Based Reasoning}

An experience-based approach or Case Based Reasoning utilizes data to diagnose case that have occurred and then provide solutions to other case that have previous case. The diagram of CBR shown at Figure 4. below:

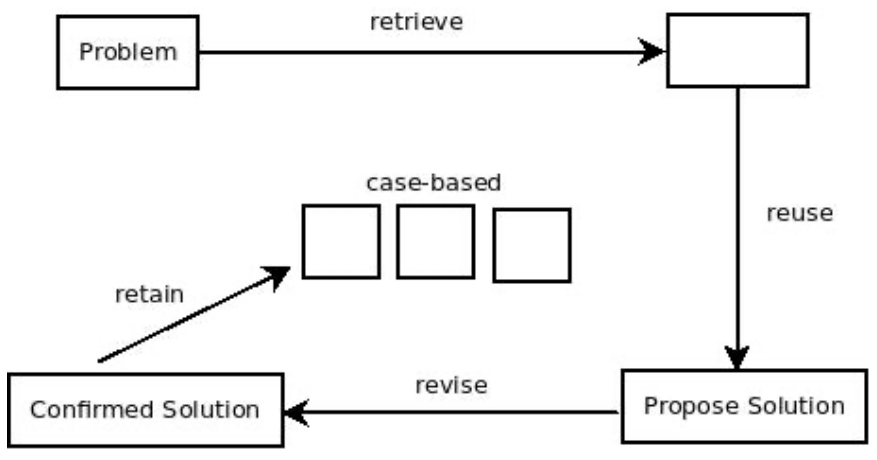

Figure. 4. Case Base Reasoning (CBR) method

Based on Figure 4. above, there are four steps in the working system of the Case-based Reasoning method. The four steps include 1.) Retrieve, which is to take back the same problems, to then carry out a search or calculation process from cases that have similarities, 2.) Reuse, which is to reuse information and knowledge contained in cases that have been obtained in the Retrieve step to be used in dealing with new cases, 3.) Revise, which is to review the solutions provided related to the problems being handled, 4.) Retain, which is to explore parts of previous experience and knowledge to can be used in solving the next problem. Every time a new problem is solved, it will start again from Retrieve step.

\subsection{Study of Literature}

Data were obtained from literature studies and case studies in the field, to be able to obtain some information about Covid19, the category of Covid19 (Covid19 with general symptoms, uncommon symptoms, and rigid symptoms), symptoms that arise from each category, as well as the relationship between symptoms and symptoms. category on Covid19. Discussions were also held with experts involving health workers in their fields. These data become data sources to be processed by the application using the Case-Based Reasoning (CBR) method.

\subsection{Data Collection}

Covid19 has three categories where each category has its symptoms and treatment. Table 1. presents each category along with symptoms and their medical treatment, which will be the reference for the application in handling input data from users related to self-diagnosis:

Table 1. Three categories of Covid19 with symptoms and medical treatment

\begin{tabular}{|c|c|c|}
\hline Covid19 Category & Symptom & Medical Treatment \\
\hline Covid19 with rigid symptoms & dyspnea or cardiovascular disease, aphasia & $\begin{array}{l}\text { If you have symptoms like these, } \\
\text { immediately contact the nearest }\end{array}$ \\
\hline
\end{tabular}

The Implementation and Testing of Online Self-Diagnose Covid19 Application ... (I Putu Agus Eka Pratama) 
Based on Table 1. above, there are three categories for Covid19. These data were obtained from experts in the health sector (especially those related to Covid19) as well as from several kinds of literature. Each category has its symptoms and each category also has its medical treatment, so there is a relationship between these data. The data for the Covid19 category, symptom data from each category, as well as medical treatment actions carried out for each category, become a reference for the application to carry out an online diagnosis process. The application also requires input data from the user in the form of a choice of complaints or symptoms experienced, which are inputted by the user through face-to-face applications when selecting the diagnosis menu. The application will read every symptom or complaint entered by the user through the system, then match it with the relationship between symptoms and categories and their treatment, to then be presented in the form of diagnostic information. The results of this diagnosis are then displayed back to the user through a face-to-face application.

\subsection{Requirement Analysis}

In the requirement analysis stage, analysis is taken from information collected about Covid19, its categories, symptoms, and the relationship between them, to support the program development process. After obtaining the required information, then the prerequisite analysis is carried out to complete the functional and non-functional requirements of the system before developing the application.

\subsection{Flowchart Diagram}

Through flowchart diagrams, the flow of processes carried out in research can be shown by involving users in it. In this research, the process flow starts from account registration (Sign Up) for new users, then login into the system. Administrators and experts can directly log into the system according to the account that has been registered. Furthermore, users can start doing online Covid19 self-diagnosis by selecting the diagnosis menu, selecting several symptoms experienced through face-to-face applications, then the system will process these data into diagnostic data. Users can view the online self-diagnosis result and print it if needed.

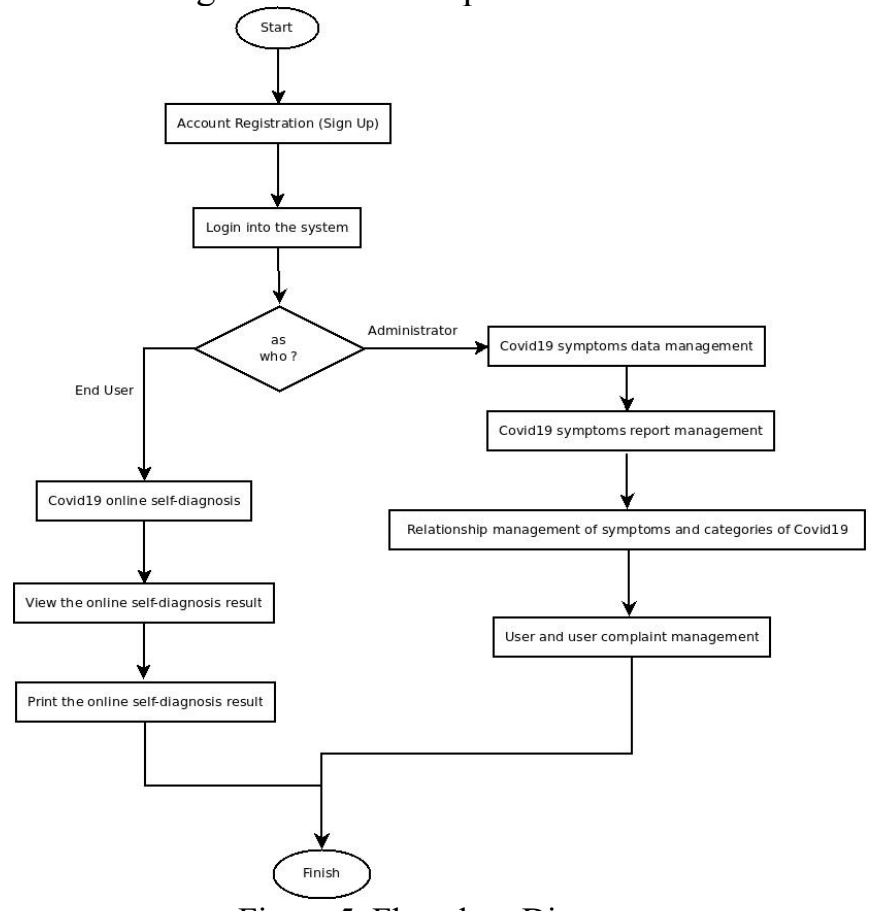

Figure 5. Flowchart Diagram 
Administrators can carry out Covid19 symptom management, Covid19 symptom report management, relationship management of symptoms and categories of Covid19, as well as user management and user complaint management. From this explanation, the flowchart diagram can be shown in Figure 5.

\section{RESULTS AND DISCUSSION}

\subsection{Covid19 Self-Diagnose Testing}

After developing the Covid19CBR application prototype, then self-diagnosis testing is carried out. When accessing the application for the first time, users can get important information about Covid19 on the front page of the website. The application starts the initialization of symptom data from each Covid19 category and their relationships, to then be displayed in the face of the application. Users who have logged into the system can choose one or more symptoms experienced, which are displayed through the application menu. These data become input data for the application to then process the relationship between symptoms and categories along with the medical treatment carried out, based on the CBR method. The diagnostic results will be directly displayed by the application to the user. Figure 6., Figure 7., and Figure 8. below show the sequence of processes described above:

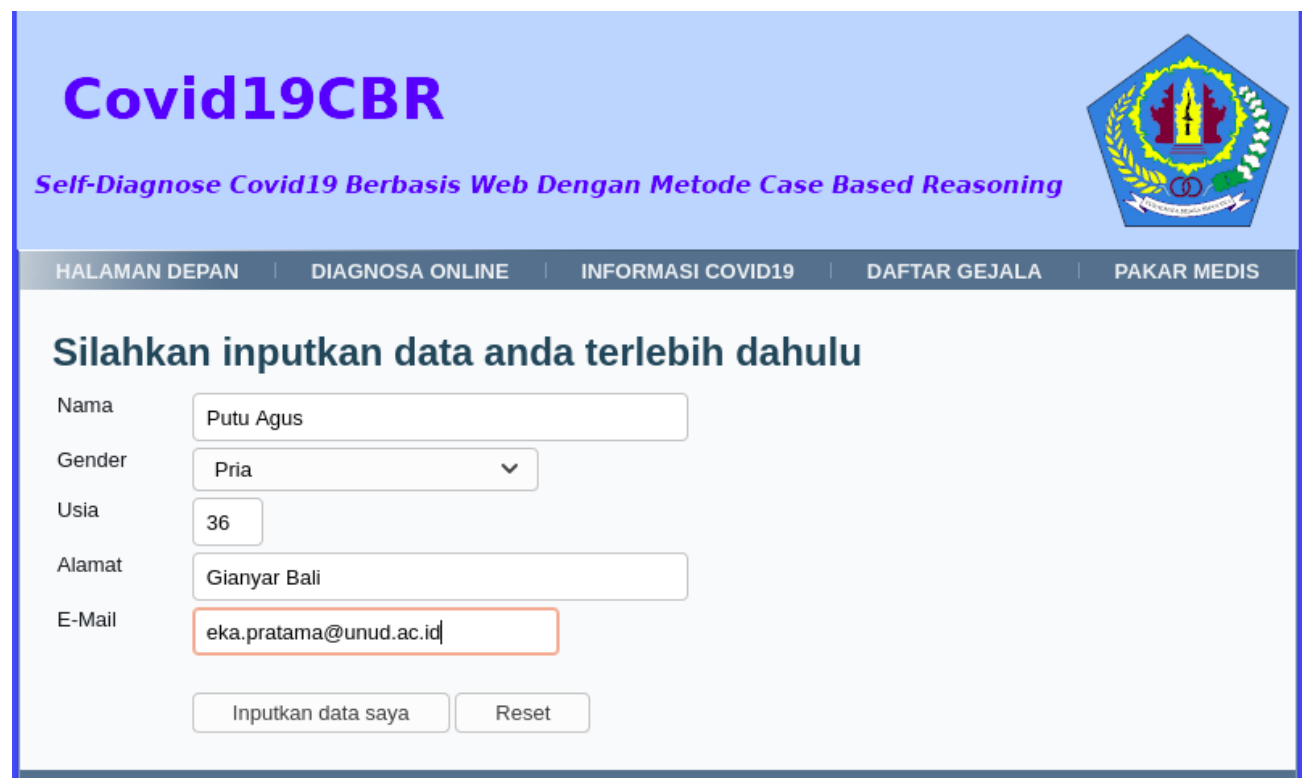

Figure 6. User input their data

From Figure 6. above, users can input their data, which includes: name, gender, age, address, and E-Mail. This data will be stored by the application into the database, to be used in completing the diagnostic results. 


\section{Covid19CBR}

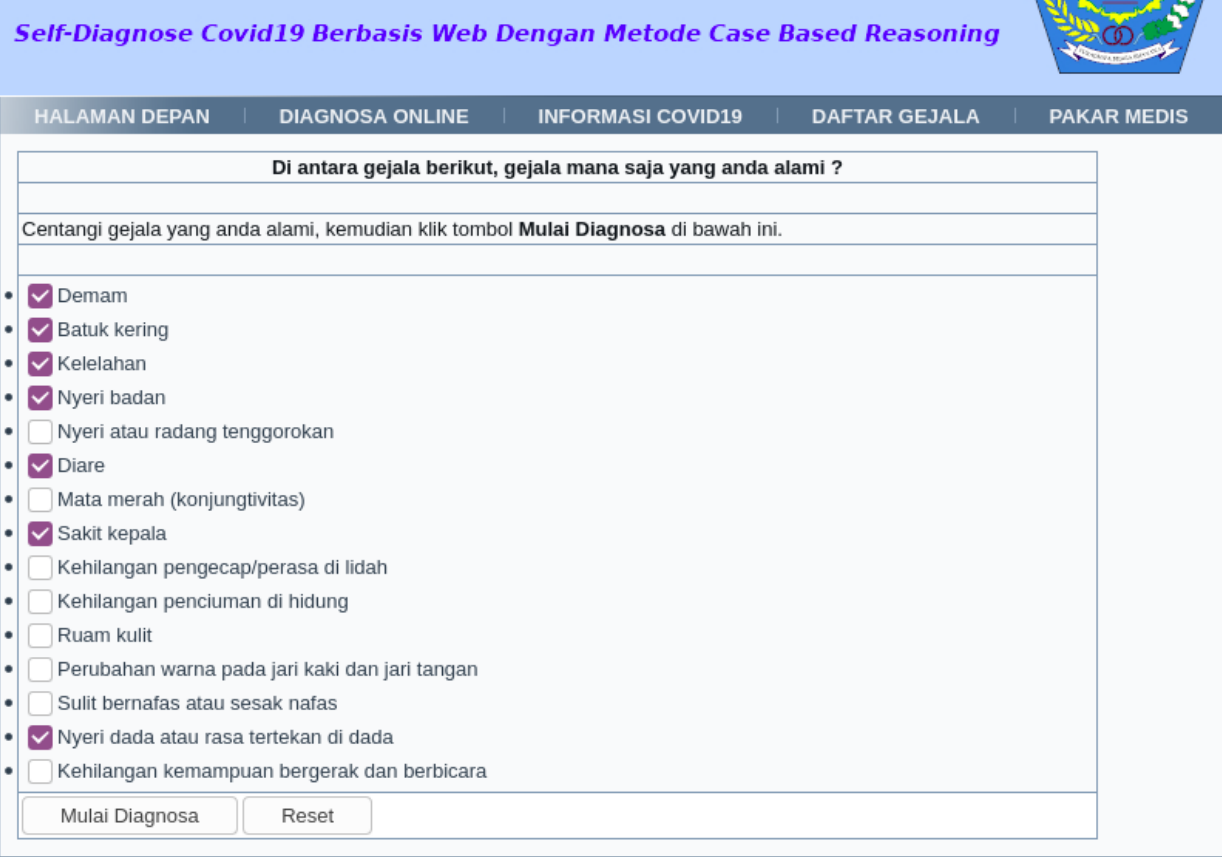

Figure 7. User selects symptoms

Based on Figure 7. above, users can use the online diagnostic service after registering in the system and logging into the system. Users can choose an online diagnosis menu, and then select several options for the symptoms they experience. The user input data will be processed by the application using the Case-Based Reasoning (CBR) method to become the results of an online diagnosis.

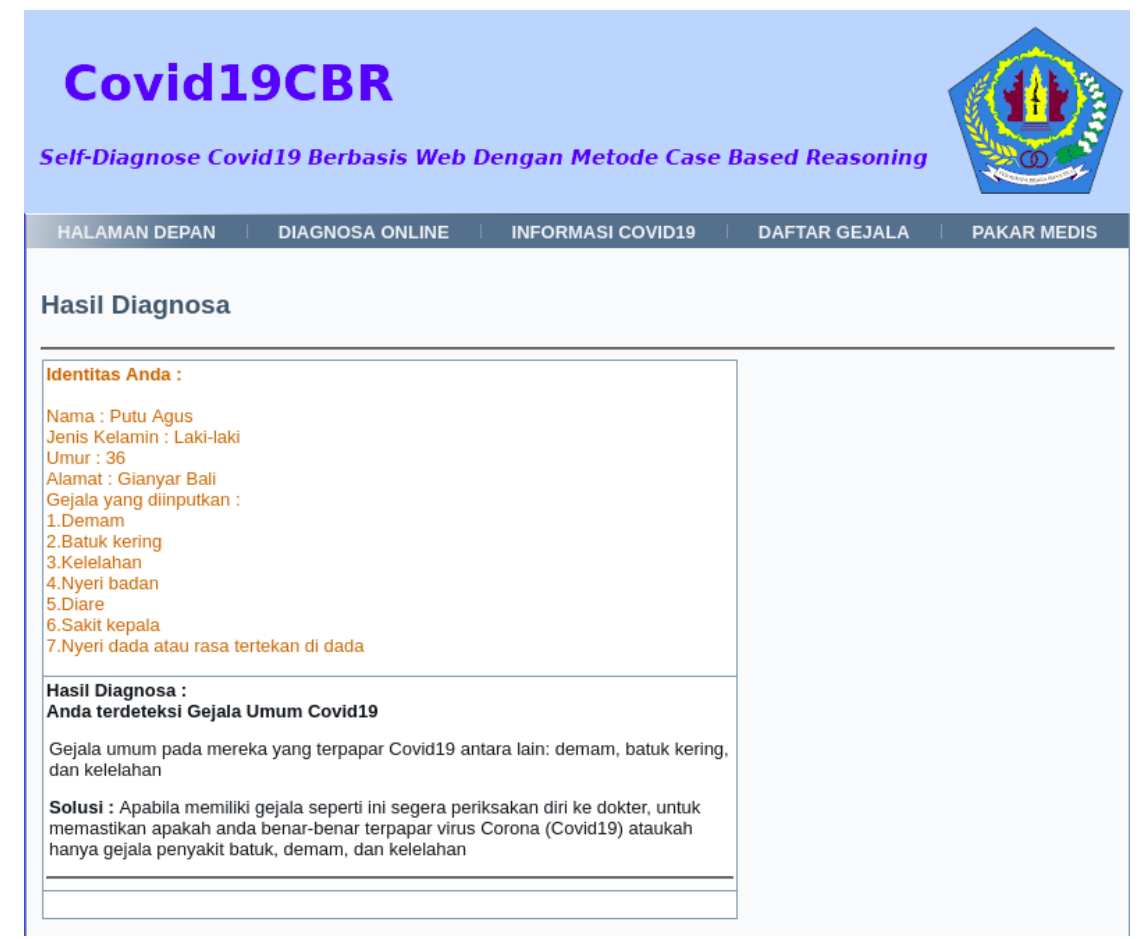

Figure 8. The application displays the diagnostic results to the user 
Based on Figure 8. above, after the user selects the symptom data experienced and presses the action button, the application will immediately process the data into online diagnostic data, accompanied by the relevant user data which is inputted into the application during the registration process. The online diagnostic results are displayed to the user through the face-to-face application.

\subsection{User Acceptance Testing (UAT)}

UAT (User Acceptance Testing) was carried out in this research through a questionnaire to 100 respondents. The question asked is: What do you think about the use of the Covid19CBR application? There are two answer choices provided for respondents as an assessment, namely Easy (with a weight of 4) and Difficult (with a weight of 2). From 100 respondents, 90 respondents chose the easy answer and 10 respondents chose the difficult answer.

From this data, the total score can be calculated by adding up the multiplication results of the number of respondents who chose each answer with the weight of each choice. So in this case, the total score of 100 respondents is $(90 \times 4)+(10 \times 2)=360+20=380$. From this total score, with a total of 100 respondents, the average value is the total score/total respondents $=380 / 100=3.80$. From this average value, the percentage value for UAT can be calculated by the formula (highest average value/weight) $\times 100 \%=(3.80 / 4) \times 100 \%=95 \%$.

Table 2. below shows the questions asked on the UAT, the two answer choices given to the respondents as an assessment along with the weight, total score, average value, and percentage value for the UAT, as explained above:

Table 2. User Acceptance Testing (UAT) assesment

\begin{tabular}{|c|c|c|c|c|c|c|}
\hline \multirow[t]{2}{*}{ No } & \multirow[t]{2}{*}{ Question } & \multicolumn{2}{|c|}{$\begin{array}{c}\text { Answer Choice } \\
\text { with Weight }\end{array}$} & \multirow[t]{2}{*}{ Total Score } & \multirow[t]{2}{*}{ Average Value } & \multirow[t]{2}{*}{$\begin{array}{l}\text { Percentage Value } \\
\text { for UAT }\end{array}$} \\
\hline & & $\begin{array}{l}\text { Easy } \\
(4)\end{array}$ & $\begin{array}{c}\text { Difficul } \\
\mathrm{t}(2)\end{array}$ & & & \\
\hline 1 & $\begin{array}{l}\text { What do you think about the } \\
\text { use of the Covid19CBR } \\
\text { application? }\end{array}$ & 90 & 10 & $\begin{array}{l}(90 \times 4)+ \\
(10 \times 2)=360+ \\
20=380\end{array}$ & $380 / 100=3.80$ & $\begin{array}{l}(3.80 / 4) \\
100 \%=95 \%\end{array}$ \\
\hline
\end{tabular}

Figure 9. below shows a pie chart of UAT results with a combination of blue and red colors with a UAT value of $95 \%$ :

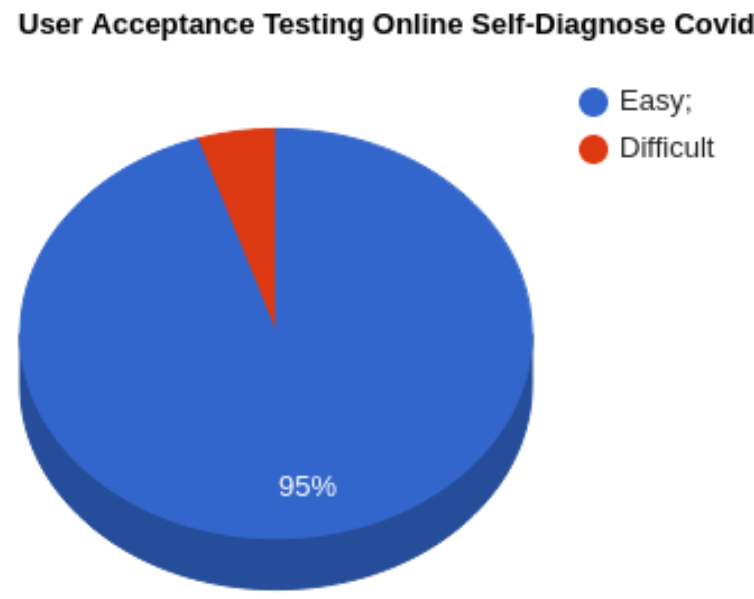

Figure 9. Pie chart of UAT result

Based on the pie chart in Figure 9. above, it can be seen that with a UAT value of $95 \%$, most respondents find it easy to use the Covid19CBR application as a Covid19 self-diagnostic, where the red color is for the symbol of the respondent who chose Easy and the blue color is for respondents who chose Difficult. 


\section{CONCLUSION}

Based on the development of the Covid19CBR application as a self-diagnosing online service along with the $95 \%$ User Acceptance Testing (UAT) results, it can be concluded that the application has been running well according to the design and purpose and most users are easy to use the Covid19CBR application in diagnosing Covid19 online. In addition to making it easier to obtain online diagnostic services to find out whether they are potentially exposed to Covid19 or not, users are also helped by the availability of information services related to Covid19 which are also provided by the application. In the future, this research can be continued, for example, the development of applications that are tailored to the needs of users and the situation of the Covid-19 pandemic.

\section{ACKNOWLEDGEMENTS}

Gratitude to Rumah Sakit Universitas Udayana for the information about Covid19 and Covid19 pandemic, Universitas Udayana for the support and funding during this research (PUPS 2021 Batch 2 Research Grant), also Indonesian Linux Community and Indonesian Open Source Community for the support, sharing, and discussion.

\section{REFERENCES}

[1] Info Corona Provinsi Bali. Pemerintah Provinsi Bali. 2021. (online).

Retrieved: https://infocorona.baliprov.go.id/

[2] Perkembangan Penyebaran Virus Corona. Dinas Kesehatan Provinsi Bali. 2020. (online).

Retrieved: https://www.diskes.baliprov.go.id/portfolio/perkembangan-penyebaran-virus-corona/

[3] Covid19. Pemerintah Kota Denpasar. 2020. (online).

Retrieved: https://safecity.denpasarkota.go.id/id/covid19

[4] Y.A. Gerhana, H.R. Sudanyana, T. Budiman, "Case Based Reasoning (CBR) dan Pengembangan Kemampuan Penyelesaian Masalah," Jurnal ISTEK, Vol.7, No.1, 2013.

[5] M.Y.C. Mage, dkk.,"Case Based Reasoning Untuk Mendiagnosa Penyakit Anak Menggunakan Metode Blockcit," J-ICON, Vol. 5 No. 2, 2017.

[6] F. Adiba, dkk., "Diagnosa Penyakit Kulit Menggunakan Case Based-Reasoning dan Self Organizing Maps," Indonesian Journal of Fundamental Sciences, Vol.06, No.01, 2020.

[7] T. Rismawan, S. Hartati, "Case-Based Reasoning untuk Diagnosa Penyakit THT (Telinga Hidung dan Tenggorokan)," Jurnal EPrint MDP, 2016.

[8] C.S. Fatoni, F.D. Noviandha, "Case Based Reasoning Diagnosis Penyakit Difteri dengan Algoritma KNearest Neighbor," Creative Information Technology Journal (CITEC Journal), Vol. 4 No. 3, 2017.

[9] S.W. Nasution, N.A. Hasibuan, P. Ramadhan, "Sistem Pakar Diagnosa Anoreksia Nervosa Menerapkan Metode Case Based Reasoning," Jurnal Konferensi Nasional Teknologi Informasi dan Komputer (KOMIK), Vol.1, No.1, 2017.

[10] F. Akmal, S. Winiarti, "Sistem Pakar Untuk Mendiagnosa Penyakit Lambung Dengan Implementasi Metode CBR (Case-Based Reasoning) Berbasis Web, Jurnal Sarjana Teknik Informatika, Vol.2 No.1, 2014.

[11] D.A. Kusuma, C.Chairani, "Rancang Bangun Sistem Pakar Pendiagnosa Penyakit Paru-Paru Menggunakan Metode Case Based Reasoning," Jurnal Infotel, Vol.6 No.2, 2014.

[12] M. Shaid, Y.S.W. Laksito, Y.R.W. Utami, "Sistem Pakar Pertumbuhan Balita Berbasis Web Dengan Metode Case Based Reasoning," Jurnal Teknologi Informasi dan Komunikasi Sinar Nusantara, Vol. 3 No. 1., 2015.

[13] A.A.H.S. Gulo, M. Syahrizal, "Perancangan Aplikasi Sistem Pakar Mendiagnosa Penyakit Hemofilia Pada Manusia Menerapkan Metode Case Based Reasoning," Jurnal Pelita Informatika, Vol.6 No.3, 2018.

[14] R.M. Sidabutar, "Sistem Pakar Mendiagnosa Penyakit Sistem Kardiovaskuler Pada Lansia Dengan Menggunakan Metode Case Based Reasoning," Jurnal Riset Komputer, Vol.6 No.1, 2019.

[15] N.Amaliah, A.Johar, I.W. Dharmayana, "Implementasi Metode Case Based Reasoning (CBR) Dalam Menentukan Klasifikasi Anak Yang Mengalami Reterdasi Mental (Studi Kasus SLB Yayasan Dharma Wanita Bengkulu)," Jurnal Informatika Rekursif, Vol.5 No.1, 2017.

[16] R. Adawiyah, "Case Based Reasoning Untuk Diagnosis Penyakit Demam Berdarah," Jurnal Ilmiah Penelitian dan Penerapan Teknologi Sistem Inrormasi (INSENTIF), Vol.1 No.1, 2017.

[17] M. Papuangan, "Penerapan Case Based Reasoning Untuk Sistem Diagnosis Penyakit Hepatitis," Jurnal Informatika dan Komputer, Vol. 1 No.1, 2018. 
[18] W. Ginting, "Sistem Pakar Mendiagnosa Penyakit Ginjal Menggunakan Metode Case Based Reasoning," Journal Information System Development (ISD), Vol 3., No. 2, 2018.

[19] C. Nas, "Sistem Pakar Diagnosa Penyakit Gigi Dan Mulut Menggunakan Metode Case-Based Reasoning," DIGIT Journal, Vol. 9, No. 2, 2019.

[20] D.F. Widyanti, B. Noranita, "Sistem Deteksi Penyakit Reumatik Artritis Menggunakan Metode CaseBased Reasoning Berbasis Web," Jurnal Masyarakat Informatika (JMASIF), Vol. 7, No. 2, 2016.

[21] Zaidir, "Testing the Management Information System of the Activity of the Task Management of Women and Children with the Black Box Test and User Acceptance Test Method," Proceeding Seminar Nasional UNRIYO, 2020.

[22] E. Listiyan, E.R. Subhiyakto, "Rancang Bangun Sistem Inventory Gudang Menggunakan Metode Waterfall (Studi Kasus Di CV. Aqualux Duspha Abadi Kudus Jawa Tengah)," KONSTELASI: Konvergensi Teknologi dan Sistem Informasi, Vol. 2, No. 3, 2019.

[23] W.S. Wardhono, Marji, L.P. Kusuma, "Evaluasi User Acceptance Testing Augmented Reality Triage Mobile Pada Sistem Kedaruratan Medis," proseding Seminar Teknologi dan Rekayasa (SENTRA), 2015.

[24] I.P.A.E. Pratama, "UAT Sistem Pendataan Penduduk Pendatang di Kabupaten Gianyar Berbasis Hybrid Cloud," Prosiding Seminar Nasional Pendidikan Teknik Informatika (SENAPATI) Ke-9, 2018.

[25] B. Priyatna, L. Hananto, M. Nova, "Application of UAT (User Acceptance Test) Evaluation Model in Minggon E-Meeting Software Development," SYSTEMATICS, Vol. 2, No. 3, pp. 110-117, 2020.

[26] E.L. Hady, K. Haryono, N.W. Rahayu, "User Acceptance Testing (UAT) pada Purwarupa Sistem Tabungan Santri (Studi Kasus: Pondok Pesantren Al-Mawaddah)," Jurnal Ilmiah Multimedia dan Komunikasi, Vol. 5, No. 1, 2020.

[27] K. Peffers, T. Tuunanen, M.A. Rothenberger, S. Chatterjee, “A Design Science Research Methodology for Information System Research,” Vol. 24, Issue 3, 2007, pp. 45-78.

[28] D. Dilson, and N. Noviardi, "Metode DSRM Dalam Pelaksanaan dan Penatausahaan Alokasi Dana Desa," Jurnal RESTI (Rekayasa Sistem Dan Teknologi Informasi), Vol. 1, No. 3, pp.217-225, 2017.

[29] G.H.T. Ling, et al., "A DSR Methodology for Conceptual Solution Development of Public Open Space Governance," Journal of Regional and City Planning, Vol. 32, No. 1, pp.16-35, 2021.

[30] P.H. Rantelinggi, A. Irianti, D. Aryanto, "Implementasi Layanan Aplikasi Bergerak Untuk Informasi Wisata Provinsi Papua Barat," JTIIK Jurnal Informasi dan Teknologi Komputer, Vol 7, No. 5, 2020. 